O. Malyeyeva ${ }^{1}$, V. Kosenko ${ }^{2}$, Yu. Davydovskyi ${ }^{1}$, D. Boiev ${ }^{1}$

${ }^{1}$ National Aerospace University "Kharkiv Aviation Institute", Kharkiv, Ukraine

${ }^{2}$ State Enterprise "National Design \& Research Institute of Aerospace Industries", Kharkiv, Ukraine

\title{
FACTOR SYNERGY ANALYSIS AND MERGER STRATEGY MODELS IN INVESTIGATION OF TELECOMMUNICATION OPERATORS' PERFORMANCE
}

\begin{abstract}
The subject of the study is the process of choosing a strategy to improve the effectiveness of telecom operators, given the trend of growth in multitraffic in data networks. The purpose of the work is to analyze the synergy of factors and develop models of traffic of data networks in the implementation of the strategy of merger of telecommunication operators. The following tasks are solved in the article: analysis of telecommunication development strategies; building a network model of synergistic effect in the implementation of development strategies; development of a model of data flow intensity in the integrated networks. The following research methods are used: statistical and system analysis, cause and effect models, mathematical programming models, and vector matrix models. The following results are obtained: The tendencies of development of multiservice services in the sphere of infocommunications are considered. Here are some basic strategies for developing a communications company. It is shown that merger and acquisition strategies are nowadays a means of integrating the necessary resources, contributing to competitive advantage. A mathematical model of linear programming is used to make the decision to invest in development strategies. The task of evaluating the effectiveness of development towards expanding the number of service users is considered. A network model in the form of a cause and effect diagram to investigate the mutual influence of sales factors was formed. The economic manifestation of the synergistic effect of companies in the implementation of the merger strategy is considered. A multilevel data flow model is used to study the intensities of data flows in a unified network. Conclusions: Due to the increasing volume and heterogeneity of infocommunication network traffic, telecom operators are using merger strategies to pool network management resources. Thus there is a synergistic effect of factors affecting sales of services. The changes in traffic and performance of the consolidated network structure are investigated on the basis of a three-tier hierarchical model. The direction of further research is to simulate network load with different technical structure characteristics to evaluate the effectiveness of a reengineering strategy.
\end{abstract}

Keywords : telecom operators; data networks; development strategies; influence of factors; traffic intensity.

\section{Introduction}

The rapid growth of traffic and the change in its structure, the need to provide services to a growing number of mobile users determines the modern requirements for data networks. The traditional network architecture will no longer be able to handle growing user requests in the near future. The development of information and communication technologies, new principles for building communication networks, changing the structural composition of subscribers and the range of services provided are all factors that significantly influence the parameters of traffic and cause the creation of new mathematical models of its research.

The introduction of new services (especially services related to video traffic) will increase the load on data networks. In addition, the networks function as multiservice using the latest IP technologies. The level of loading of the border nodes is $60-70 \%$ already. Further increase in load through the introduction of new services requires analysis of their efficiency and study of forecast traffic.

Effective decisions must be made regarding the choice of network development strategies to maximize the use of its resources. Setting up a flexible traffic management system takes time, knowledge and considerable resources. A comprehensive analysis of network resources and traffic should be undertaken to form a decision-making system for managing network development. The main tasks in managing traffic are minimizing packet loss and delays, optimizing bandwidth and ensuring quality of service.
Reviewing publications and setting a task. Despite the considerable number of theoretical and methodological publications on management of activity of telecommunication and telecommunication operators, enterprises of the telecommunication industry, in the existing publications, only relations from the positions of supplier (equipment manufacturers) and consumer (operators and providers) are considered [1 - 5]. The process of formation and implementation of strategies for the development of telecommunication operators to maintain the efficiency of their activity in the conditions of heterogeneous and growing traffic remains insufficiently studied [6, 7]. In addition, the development of economic relations in the field of data transmission causes the expansion of the sphere of cooperation of telecommunication operators on the basis of cooperation and integration $[8,9]$. These processes are also poorly understood from the point of view of data transmission efficiency in the unified networks.

Therefore, the purpose of the article is to investigate the synergy of factors of activity of telecommunication operators and to develop models of traffic of data networks in the implementation of the merger strategy.

The following tasks are solved:

1) analysis of telecommunications development strategies;

2) building a network model for the study of synergistic effect in the implementation of development strategies;

3) development of a model of data flow intensity in the integrated networks. 


\section{Main part}

1. Analysis of development strategies of the operators. The modern development of infocommunication services is characterized by an increase in the volume of traffic (Fig. 1), which is caused by the growth of consumption of "bulk" types of content (Fig. 2) [10]. In addition, the information market is characterized by increased competition of its participants $[11,12]$. This leads to the need for companies to find and apply the most effective development strategies [8]. For example, Jio and Microsoft are competing for and deploying advanced technologies such as data analytics, artificial intelligence, cognitive services, blockchain, the Internet of Things and peripheral computing. AT\&T Communications and Microsoft have formed a long-term alliance that will utilize innovative technologies such as cloud computing, AI and 5G. SK Telecom and Microsoft are partner operators and plan to test gaming streaming capabilities [13].

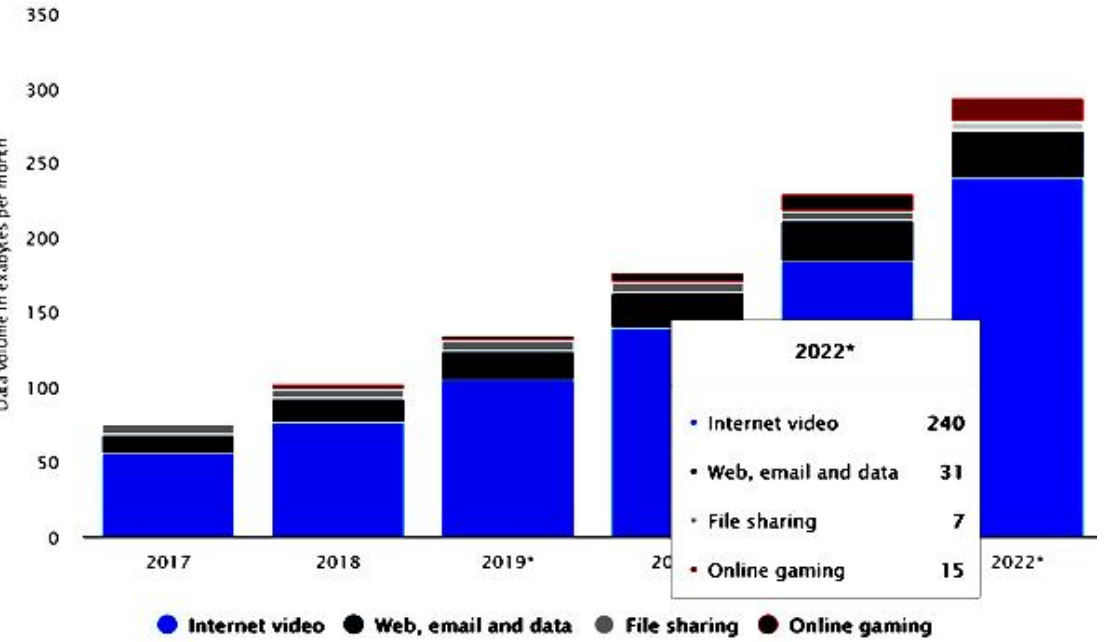

Fig. 1. The trend of increasing the consumption of communications services

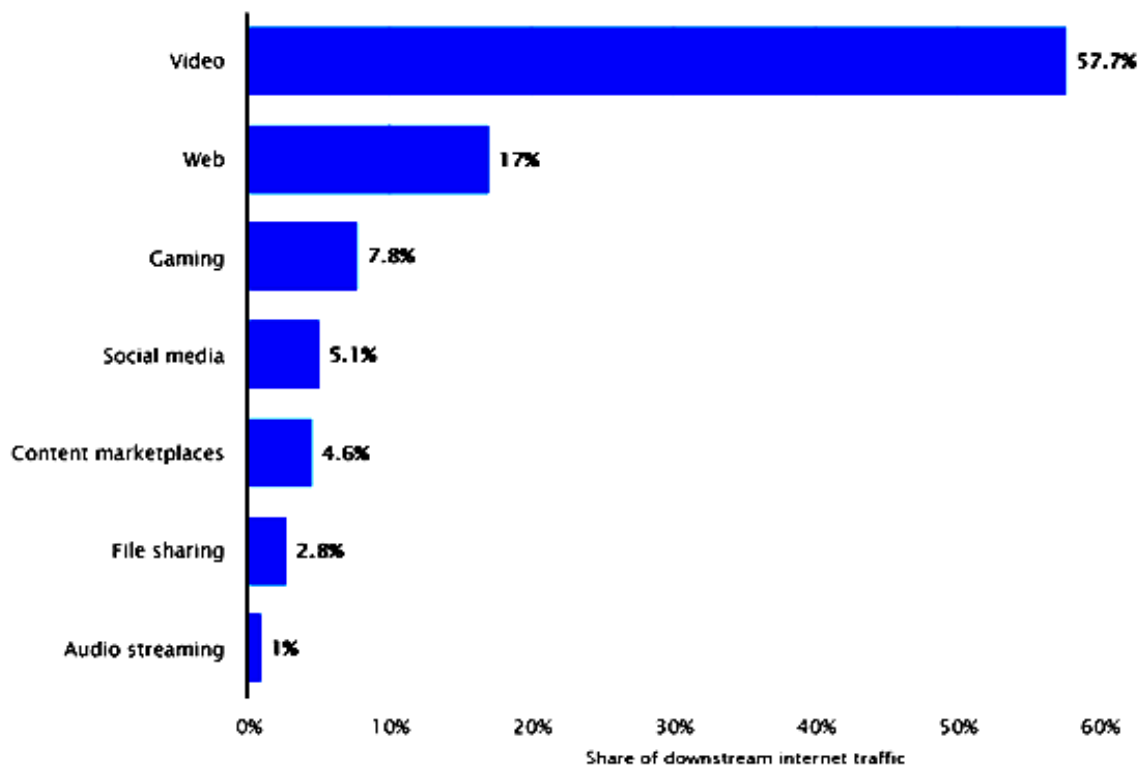

Fig. 2. Distribution of different types of content when consuming telecommunication services

Depending on the development goals of the company, there are three main types of strategies [8]:

- growth strategy, including sub-strategies of concentration, integration and diversification (Fig. 3);

- stabilization strategy that includes reengineering (redesign), mass service provision and termination of investment;

- protection and survival strategy that includes mergers and acquisitions.

Growth strategies are aimed at expanding market activities, increasing operator assets, increasing investment. Stabilization, protection and survival strategies are applied by major operators who already dominate the market and aim to preserve it. There is a search for internal reserves and profitable opportunities with minimal risk. This strategy is used by businesses at the stage of the life cycle.

In addition, there is also a downsizing strategy that includes business restructuring, bankruptcy and liquidation. Reduction strategies have the primary purpose of minimizing company costs for those business processes that are unprofitable. But in this article, we only look at the strategies that characterize the campaign's development to some extent. 


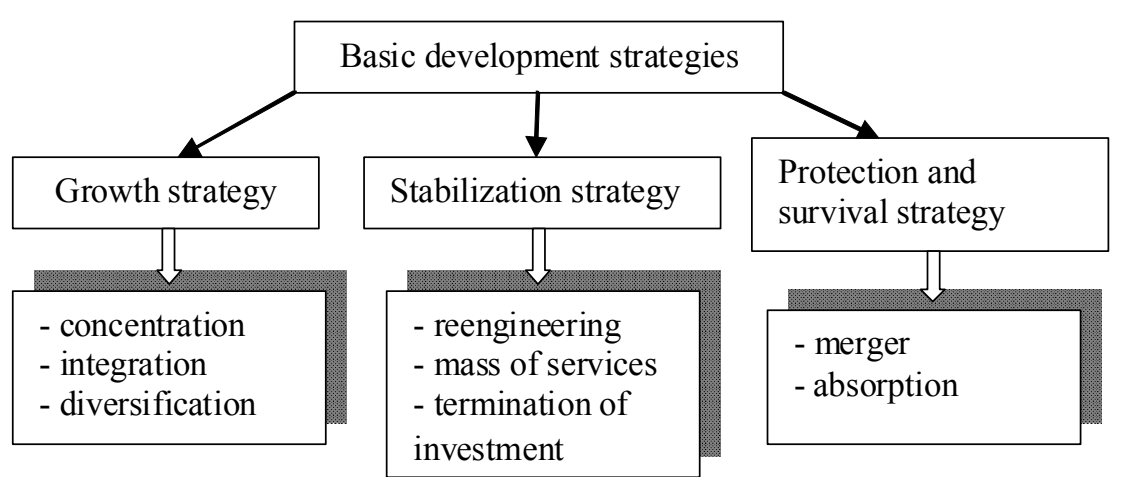

Fig. 3. Basic strategies for developing communications companies

The integration of M\&A processes has led to an increase in M\&A market volumes in recent years [9]. Therefore, these strategies are a means of integrating the necessary resources, which contributes to the achievement of competitive advantages. Depending on the type of integration (vertical or horizontal), the integration of telecommunication operators enables to increase the volume of consumption and increase the diversification of services. In addition, there is a synergistic effect, which is understood as an overall increase in the effectiveness of integration activities [8].

Leading operators are developing a new business model that leverages existing production resources in developed market segments or develops them through merger and acquisition strategies. The merger strategy is also used to address traffic management issues and ensure that users have access to information resources.

To make the decision to invest in the most effective development strategies, a mathematical model of linear programming is used in which the objective function is maximized:

$$
F_{\text {max }}=\sum_{i=1}^{5} a_{i} x_{i}
$$

where $a_{i}-$ the weights on the estimates of investment efficiency; $x_{1}$ - efficiency of investment in new communication services and technologies; $x_{2}-$ efficiency of investments in technological re-equipment; $x_{3}$ - efficiency of investments in improvement of operational activity; $x_{4}$ - effectiveness of investment in the development of innovative infrastructure; $x_{5}-$ efficiency of investment in management for entering new markets (expanding the circle of consumers).

Investment performance is defined as

$$
x_{i}=y_{i} / d_{i},
$$

where $y_{i}$-investment income, $d_{i}$ - volume of investments.

The problem is solved with restrictions on the total amount of investment:

$$
\sum_{i=1}^{5} d_{i} \leq D .
$$

Forecasting methods based on generalized industry development indicators are used to determine investment performance weights [14].

Consider the task of evaluating the effectiveness of development towards expanding the number of service users. It should be noted that there is no linear dependence of financial indicators (income of operators) of the market on the number of consumers [15, 16] Thus, in simplified form, the average revenue per subscriber is determined by the formula $Y=N \times S$, where $N$ is the volume of consumption of services (number of consumers), $S$ - cost of services.

Thus, as consumers grow, revenue should increase in proportion. But in the context of price competition, there is a tendency to significantly reduce the cost of services, which in turn slows revenue growth. As an example Fig. 4 shows the profits of the Vodaphone division in Germany [10].

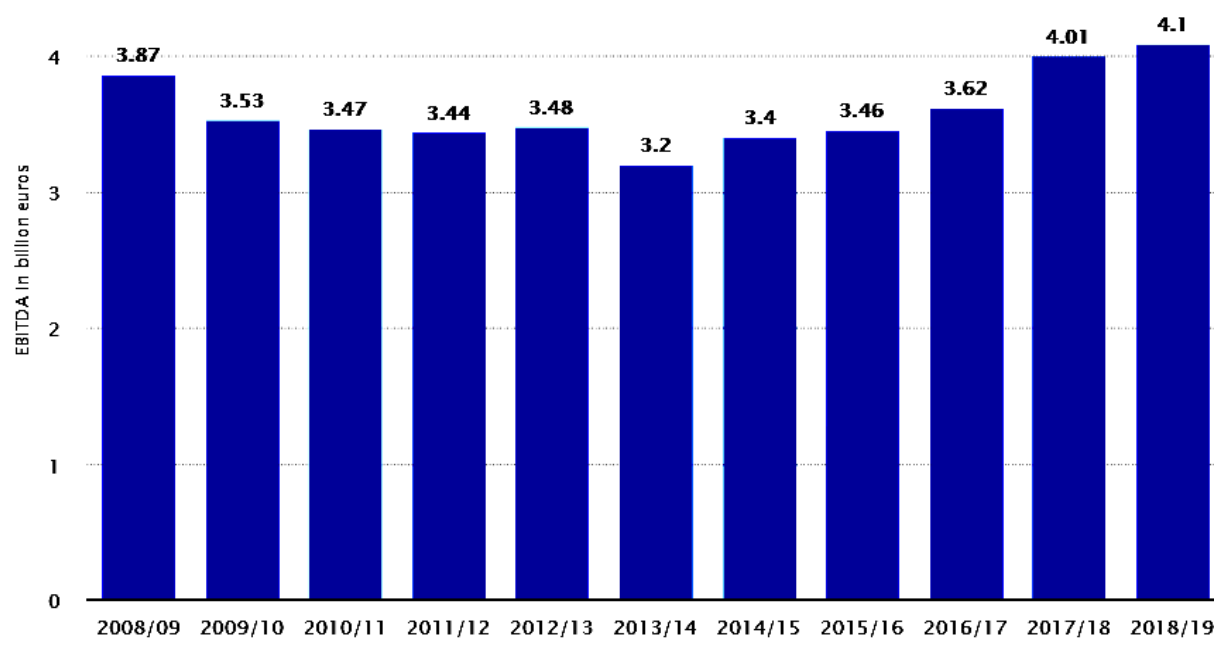

Fig. 4. The trend of changing the profit of the carrier 
The figure shows a fall in revenues of $16 \%$ by 2013 , followed by a $22 \%$ increase in revenues. If you relate this data to the trend of a steady increase in traffic (see Fig. 1), the change in revenue can be explained by the overall decrease in the price of data transmission and at the same time the rapid increase in the volume of traffic after 2014.

2. Network model of synergistic effect in the implementation of development strategies. When studying the effectiveness of investments in the field of infocommunications, the synergistic effect associated with the size of the operator's network and the number of subscribers should be taken into account [17-23]. With increasing number of consumers, the following effects occur:

- communicative aspect, which means effective exchange of information and development of the contact network;

- content that enhances the value of the network in terms of content distribution and aggregation; loyalty.

- brand of a company that increases customer

You can distinguish the following factors, which affect the sales of your business (which leads to an increase in its efficiency) and are related in turn:

a) factors that are directly controllable:

- network scale,

- operational activity,

- financial investments,

- level of management;

b) second-order management factors (which depend on the factors of group a):

- number of users,

- customer loyalty.

To investigate the network effect of the interaction of these factors [24], it is necessary to construct a cause and effect diagram with the corresponding coefficients of influence (interaction of factors) (Fig. 5).

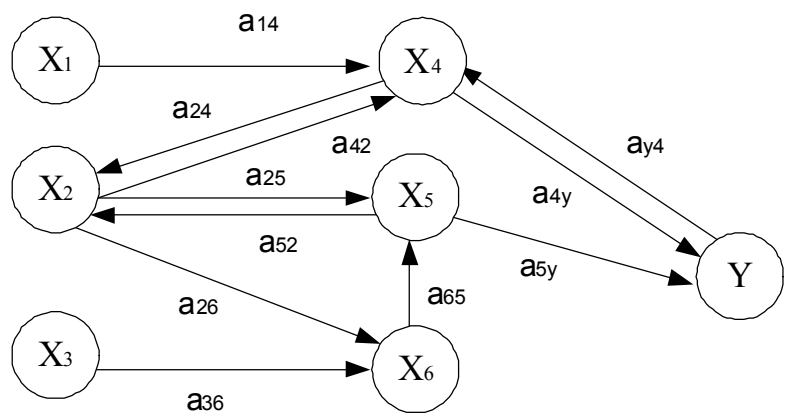

Fig. 5. Cause-and-effect diagram of the mutual influence of factors of sales volume of services of the company

The figure shows: studied variable $Y$ - sales volume and multiple factors $X_{I}$ - operating activities, $X_{2}$ - financial investments, $X_{3}$ - level of management, $X_{4}$ - scale of network $X_{5}$ - number of users, $X_{6}$ customer loyalty; impact factors $-a_{i j}$ and $a_{i y}, i, j=\overline{1,6}$.

It should be noted that between some elements there is mutual influence, and on the diagram there are three loops, which causes the corresponding effect of self-development.
So, for example, the factor of increase of sales volume is revealed at realization of services to a larger subscriber base (effect of critical mass) through unified channels of distribution. Metclough's law also works here, according to which the value of the network increases nonlinearly (corresponding to the square of the number of additional consumers). Expansion of the consumer market, in turn, reduces the cost of telecommunication services. Networking results in increased revenue through the use of a single infrastructure and increased customer loyalty.

Let's consider the economic manifestation of the synergistic effect of companies in the implementation of the merger strategy. The total income of both companies for the merger is defined as

$$
Y_{0}=N_{1} S_{1}+N_{2} S_{2},
$$

where $N_{1}, N_{2}$ - appropriate volumes of services provided to consumers, $S_{1}, S_{2}-$ cost of services of two operators.

As a result of the merger, the total revenue can be reported in the form:

$$
Y_{0}=Y_{\mathrm{S}}+N_{1} S_{1}+N_{2} S_{2}
$$

where $Y_{S}$ - the effect of synergy on consolidation.

Influence of network effect in the sphere of infocommunications is also non-linear, it can be expressed by an exponential function. Thus, even when the price drops after the consolidation of the operators, the revenue can be greater than the gain in network expansion, since it generates more network resources. The network effect of merging operators can be displayed using an index $(\beta)$ :

$$
Y_{0}=\mathrm{Y}_{\mathrm{S}}+\beta\left(N_{1} S_{1}+N_{2} S_{2}\right) \text {. }
$$

Consider the variants of the values of this index:

if $\beta=1$, then the increase in value from network integration did not occur and the volume of services provided is unchanged;

$\beta>1$ - there is a synergistic effect;

$\beta<1$ - only the number of consumers increases.

3. Model of the intensity of data flows in the integrated networks. Combining networks leads to changes in traffic in each network, which require decisions to effectively manage it [25]. To solve this problem, let's consider a hierarchical model, at the upper level of which the combined network is represented, the lower level is made up of separate subsystems (networks of operators before their merger) [26]. However, large operators have their own subnet level in their structure. Therefore, the tiered structure is formed, which occurs when combining networks of two or more operators (the first level of partitioning), which in turn implement unions of their own subnets (the second level) [27].

A multilevel data flow model is used to study the intensities of data flows in a unified network.

Suppose there are $k_{1}$ networks in the consolidated network (denote the network number $n=\overline{1, k_{1}}$ ). The composition of each network number $n$ is given by a vector column

$$
\left(c_{1 n}\right)^{T}=\left(c_{1 n 1}, \ldots, c_{1 n i}, \ldots, c_{1 n t}\right),
$$


where $c_{1 n i}=\left\{\begin{array}{l}1, \text { if the } \mathrm{i} \text { - th subnet is a part of the } \mathrm{n} \text { - th net; } \\ 0, \text { if the } \mathrm{i} \text { - th subnet is not a part of the n-th net; }\end{array}, \sum_{i=1}^{t} c_{1 n i} \geq 1, \sum_{n=1}^{k_{1}} c_{1 n i}=1\right.$.

From the vector columns $c_{1 n}$, you can construct a matrix that defines the networking $C_{1}=\left\|c_{1 n}\right\|$. The total intensities of data flows transmitted between network nodes are determined by a matrix $A=\left\|\alpha_{i j}\right\|$, where $\alpha_{i j}$ is the total intensities of data flows from node $i$ to node $j$ :

You can calculate the intensities of data flows between networks:

$$
A_{1}\left(C_{1}\right)=\left\|a_{1 i j}\right\|=C_{1} A\left(C_{1}\right)^{T}
$$

where $a_{1 i j}$ - total data flow intensity between node group number $i$ and node group number $j$ of the network structure :

$$
a_{1 i j}=\sum_{k=1}^{t} c_{1 j k} \sum_{r=1}^{t} c_{1 i r} a_{r k} .
$$

Let's calculate the data flows of a single user request between networks. So for the query number $k$ we get

$$
A_{1 k}\left(C_{1}\right)=\left\|a_{1 k i j}\right\|=C_{1} A_{k}\left(C_{1}\right)^{T}
$$

where $a_{1 k i j}$ - the total intensity of the request data stream number $k$ between the node group number $r$ and the node group number $j$ of the network structure

$$
a_{1 k i j}=\sum_{m=1}^{t} c_{1 j m} \sum_{r=1}^{t} c_{1 i r} a_{k r m}
$$

The results obtained allow us to estimate the data flows, respectively, the loading of the structure-forming equipment of the networks at the first level as a whole and the flows of each request.

For the second layer of the structure, we similarly define: the matrix of association of the second layer subnets in the network of the first layer; the intensity of data flows between the second level subnets; the intensity of data flows of one request between the second level subnets.

The total intensity of data flows in the network of nodes of the first level:

$$
A_{10}^{*}=\sum_{i=1}^{t} \sum_{j=1}^{t} a_{i j}
$$

The total intensity of data flows within the first tier networks:

$$
A_{1}^{*}\left(A_{1}\left(C_{1}\right)\right)=\sum_{i=1}^{K_{1}} a_{1 i i}
$$

where $A_{1}\left(C_{1}\right)$ - the total intensity of data flows that are transmitted only within the first tier networks.

Total intensity of data flows at the second level:

$$
A_{20}^{*}\left(A_{1}\left(C_{1}\right)\right)=\sum_{i=1}^{k_{1}} \sum_{j=1}^{k_{1}} a_{1 i j}-\sum_{i=1}^{k_{1}} a_{1 i i}
$$

the total intensity of data flows within the second level subnets:

$$
A_{2}^{*}\left(A_{2}\left(C_{2}\right)\right)=\sum_{i=1}^{k_{1}} a_{2 i i} .
$$

The absorption coefficients of the data flow intensities at each level are used as a measure of structure efficiency. Absorption coefficient for the first level:

$$
\sigma_{1}\left(C_{1}\right)=\frac{A_{1}^{*}\left(A_{1}\left(C_{1}\right)\right)}{A_{10}^{*}\left(A_{1}\left(C_{1}\right)\right)}, 0<\sigma_{1}<1 .
$$

Absorption coefficient for the second level:

$$
\sigma_{2}\left(C_{2}\right)=\frac{A_{2}^{*}\left(A_{2}\left(C_{2}\right)\right)}{A_{20}^{*}\left(A_{2}\left(C_{2}\right)\right)}, 0<\sigma_{2}<1 .
$$

Based on this model, the intensities of data flows between nodes, as well as the exchange of data between subnets to determine the load of communication channels and network equipment can be calculated.

\section{Conclusions}

The article discusses the strategies of development of modern telecommunication operators, caused by the increasing volume and heterogeneity of traffic of infocommunications networks.

The tendency of application of merger strategy of several operators is made, its advantages are considered.

A synergistic network effect model has been developed under the conditions of operator unification. The model allows us to evaluate the impact of changing the quantitative parameters of the network on the change of its economic efficiency indicators.

A three-level hierarchical network model is used to study traffic changes and the effectiveness of the combined network structure.

The direction of further research is to simulate network load with different characteristics of the technical structure to evaluate the effectiveness of a network conversion strategy development.

\section{REFERENCES}

1. Koval, V. V. (2015), "Socio-economic efficiency of development of innovation and investment activities of telecommunications operators", Bulletin of the Volyn Institute of Economics and Management, Vol. 13, P. 154-161.

2. Pevcin, P. (2018), "The Analysis of the Implementation of municipal Cooperation and Merger Strategies: Case Study for Slovenia", Economics and Culture, No. 15 (1), P. 15-21. DOI: https://doi.org/10.2478/jec-2018-0002

3. Hong ,Y., Li, Z. and Wang, J. (2019), "Business Value of Telecom Operators' Big Data”, Journal of Physics: Conference Series, Vol. 1437, 2nd International Symposium on Big Data and Applied Statistics (ISBDAS2019) 20-22 September 2019, Dalian, China. DOI: https://doi.org/10.1088/1742-6596/1437/1/012067 
4. Smoliy, D. A. (2019), "Study of IMS capabilities for providing new services in infocommunication networks in the implementation of the FMC concept", KPI them. Igor Sikorsky, 124 p., available at: https://ela.kpi.ua/bitstream/123456789/31219/1/Smoliy magistr.pdf

5. Granaturov, V. M., Litovchenko, I. V. (2010), Communication Services Management, Kyiv : Education of Ukraine, 254 p.

6. Ulset, S (2007), "Restructuring diversified telecom operators". Telecommunications Policy, No. 31 (3), P. 209-229. DOI: https://doi.org/10.1016/j.telpol.2007.01.006

7. Zhang, X., Du, Y., Li, Z. and Wang, Q. (2018), "Analyzing the operational performance migration of telecom operators", China Communications, Vol. 15, No. 6, P. 139-157.

8. Shostak, L. V., Pavlova, S. V. (2013), "Development of corporate strategy of telecommunications operators", Efficient economy, No. 4, available at : http://www.economy.nayka.com.ua/?op=1\&z=1948

9. Makedon, V. V. (2011), "Strategies for the formation of integrated structures of international corporations as a result of mergers and acquisitions", available at : http://www.nbuv.gov.ua/portal/Soc_Gum/Vamsu_econ/2011_1/Makedon.htm

10. (2020), Statistics and market data on Technology \& Telecommunications, available at : https://www.statista.com/markets/418/technology-telecommunications/

11. Gilka, U. L. (2009), "Features of competition in the telecommunications services market", Scientific notes of the Ukrainian Research Institute of Communications, No. 3, P. 11.

12. Stryi, L. A., Orlov, V. N., Petenko, I. V., Golubev, A. K. (2004), "Formation of the market of communication services of Ukraine", Social management and management of information processes: a series of "Public Administration": Coll. Science. wash., Donetsk : Don. ДУУ, No. 31, Vol. 5, P. $329-340$.

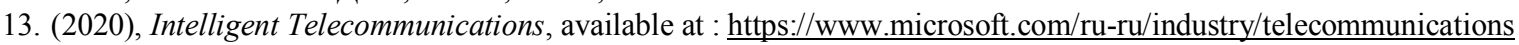

14. Filon, M. M. (2012), "Study of factors influencing the functioning of the structure of the telecommunications sector", Problems of the system approach in economy: coll. Science. pr., Kyiv : NAU, No. 41, P. 163-170.

15. Vlasova, O. A. (2009), "Building a Value Management System for a Cellular Company: Practical Aspects", Economic analysis: theory and practice, No. 36, P. 81-91.

16. Tkalich, O. P. et al. (2013), "Improving the efficiency of using the corporate network according to the BYOD concept", Problems of creation, testing, application and operation of complex information systems, No. 7, P. 77-87.

17. Davydovskyi, Y., Reva, A. and Malyeyeva, O. (2018), "Method of modelling the parameters of data communication network for its upgrading", Innovative technologies and scientific solutions for industries, No. 4 (6), P. 15-22. DOI: https://doi.org/10.30837/2522-9818.2018.6.015

18. Zhulego, V. (2008), "Modeling Mergers and Acquisitions of Companies. A few hypotheses", Economic strategies, No. 8, P. $132-140$.

19. Kosenko ,V. (2017), "Mathematical model of optimal distribution of applied problems of safety-critical systems over the nodes of the information and telecommunication network", Advanced Information Systems, Vol. 1, No. 2, pp. 4-9, doi: http://doi.org/10. 20998/2522-9052.2017.2.01

20. Svyrydov, A., Kuchuk, H., Tsiapa, O. (2018), "Improving efficienty of image recognition process: Approach and case study", Proceedings of 2018 IEEE 9th International Conference on Dependable Systems, Services and Technologies, DESSERT 2018, pp. 593-597, DOI: http://dx.doi.org/10.1109/DESSERT.2018.8409201

21. Kovalenko, A. and Kuchuk H. (2018), "Methods for synthesis of informational and technical structures of critical application object's control system", Advanced Information Systems, Vol. 2, No. 1, pp. 22-27, DOI: https://doi.org/10.20998/2522-9052.2018.1.04

22. Sviridov, A., Kovalenko, A. and Kuchuk, H. (2018), "The pass-through capacity redevelopment method of net critical section based on improvement ON/OFF models of traffic", Advanced Information Systems, Vol. 2, No. 2, pp. 139-144, DOI: https://doi.org/10.20998/2522-9052.2018.2.24

23. Kovalenko, A.A., Kuchuk, G.A. and Ruban I.V. (2018), "The use of timelines for approximating the length of queues of computer networks", The current state of research and technology in industry, No. 2(4), pp. 12-18. DOI: http://doi.org/10.30837/2522-9818.2018.4.012

24. Koval, V. V. (2013), "Strengthening the network effect of the synergy of consolidation of the subjects of the infocommunications market", Economic innovations, No. 55, P. 61-72.

25. Davydovskyi, Yu. Reva, O. Malyeyeva, O. Kosenko V. (2020), "Application of the sliding window mechanism in simulation of computer network loading parameters", Advanced Information Systems, Vol. 4, No. 1, P. 16-22. DOI: https://doi.org/10.20998/2522-9052.2020.1.03

26. Mukhin, V., Kuchuk, N., Kosenko, N., Artiukh, R., Yelizyeva, A., Maleyeva, O. etc. (2019), "Decomposition Method for Synthesizing the Computer System Architecture", Advances in Intelligent Systems and Computing, Vol. 938, P. 289300. Springer, Cham. DOI https://doi.org/10.1007/978-3-030-16621-2 27

27. Dai, R. and Tang, S. (2009), "Analysis on Vertical Integration of Telecom Operators", International Conference on Management of e-Commerce and e-Government, Nanchang, P. 277-280.

Received (надійшла) 25.02.2020

Accepted for publication (прийнята до друку) 22.04.2020

\section{ABOUT THE AUTHORS / ВІДОМОсті ПРО АВТOPIB}

Малєєва Ольга Володимирівна - доктор технічних наук, професор, професор кафедри комп'ютерних наук та інформаційних технологій, Національний аерокосмічний університет імені М. Є. Жуковського «ХАІ», Харків, Україна; Olga Malyeyeva - Doctor of Technical Sciences, Professor, Professor of the Department of Computer science and information technologies, National Aerospace University "KhAI", Kharkiv, Ukraine; e-mail: o.maleyeva@khai.edu; ORCID ID: https://orcid.org/0000-0002-9336-4182.

Косенко Віктор Васильович - доктор технічних наук, професор, помічник директора з наукової роботи, ДП “Південний державний проектно-конструкторський та науково-дослідний інститут авіаційної промисловості”, Харків, Україна; 
Viktor Kosenko - Doctor of Technical Sciences, Professor, Assistant Director for Research, State Enterprise "National Design \& Research Institute of Aerospace Industries", Kharkiv, Ukraine;

e-mail: kosv.v@ukr.ua; ORCID ID: https://orcid.org/0000-0002-4905-8508.

Давидовський Юрій Костянтинович - аспірант кафедри комп'ютерних наук та інформаційних технологій, Національний аерокосмічний університет імені М. С. Жуковського «ХАI», Харків, Україна;

Yurii Davydovskyi - graduate student of the Department of Computer science and information technologies, National Aerospace University "KhAI”, Kharkiv, Ukraine;

e-mail: davidovskyi2350@gmail.com; ORCID ID: https://orcid.org/0000-0003-2813-4169.

Боєв Дмитро Олександрович - аспірант кафедри інформаційних технологій проектування, Національний аерокосмічний університет імені М. Є. Жуковського «XАI», Харків, Україна;

Dmitriy Boiev - graduate student of the Department of Information Technologies Design, National Aerospace University "KhAI", Kharkiv, Ukraine;

e-mail: d.boev@khai.edu; ORCID ID: https://orcid.org/0000-0001-9690-8352.

\section{Аналіз синергії факторів та моделі стратегії злиття в дослідженні ефективності діяльності операторів зв'язку \\ О. В. Малєєва, В. В. Косенко, Ю. К. Давидовський, Д. О. Боєв}

Анотація. Предметом дослідження в статті $є$ процеси вибору стратегії для підвищення ефективності діяльності операторів зв'язку з огляду на тенденції зростання мультитрафіку в мережах передачі даних. Мета роботи - аналіз синергії факторів і розробка моделей трафіку мереж передачі даних при реалізації стратегії злиття операторів зв'язку. В статті вирішуються наступні завдання: аналіз стратегій розвитку операторів зв'язку; побудова мережної моделі синергетичного ефекту при реалізації стратегій розвитку; розробка моделі інтенсивності потоків даних в об'єднаних мережах. Використовуються такі методи дослідження: статистичного та системного аналізу, причинно-наслідкові моделі, моделі математичного програмування та векторно-матричні моделі. Отримано наступні результати: Розглянуто тенденції розвитку мультисервісних послуг у сфері інфокомунікацій. Наведено основні стратегії розвитку компаній 3 надання послуг зв'язку. Показано, що стратегії злиття та поглинання сьогодні виступають засобом інтеграції необхідних ресурсів, що сприяє досягненню конкурентних переваг. Для прийняття рішення з інвестування у стратегії розвитку застосовується математична модель лінійного програмування. Розглянуто завдання оцінювання ефективності розвитку в напрямку розширення кількості споживачів послуг. Сформована мережна модель у вигляді причинно-наслідкової діаграми для дослідження взаємовпливу факторів обсягу продажів. Розглянуто економічний прояв синергетичного ефекту компаній при реалізації стратегії злиття. Для дослідження інтенсивностей потоків даних в об'єднаній мережі використовується модель потоків даних багаторівневої структури. Висновки: Внаслідок зростаючих обсягів та неоднорідності трафіку інфокомунікаційних мереж операторами зв'язку застосовуються стратегії злиття для об'єднання ресурсів управління мережею. При цьому виникає синергетичний ефект факторів, що впливають на обсяги продажів послуг. Дослідження змін трафіку та ефективності структури об'єднаної мережі проводиться на основі трирівневої ієрархічної моделі. Напрямком подальших досліджень $є$ моделювання навантаження мережі з різними характеристиками технічної структури для оцінки ефективності стратегії реінжинирінгу. трафіку.

Ключов і слов а: оператори зв'язку; мережі передачі даних; стратегії розвитку; вплив факторів; інтенсивність

\section{Анализ синергии факторов и модели стратегии слияния}

в исследовании эффективности деятельности операторов связи

О. В. Малєєва, В. В. Косенко, Ю. К. Давыдовский, Д. А. Боєв

Аннотация. Предметом исследования в статье являются процессы выбора стратегии для повышения эффективности деятельности операторов связи с учетом тенденции роста мультитрафика в сетях передачи данных. Цель работы - анализ синергии факторов и разработка моделей трафика сетей передачи данных при реализации стратегии слияния операторов связи. В статье решаются следующие задачи: анализ стратегий развития операторов связи; построение сетевой модели синергетического эффекта при реализации стратегий развития; разработка модели интенсивности потоков данных в объединенных сетях. Используются такие методы исследования: статистического и системного анализа, причинно-следственные модели, модели математического программирования и векторноматричные модели. Получены следующие результаты: Рассмотрены тенденции развития мультисервисных услуг в сфере инфокоммуникаций. Приведены основные стратегии развития компаний по предоставлению услуг связи. Показано, что стратегии слияния и поглощения сегодня выступают средством интеграции необходимых ресурсов, способствуют достижению конкурентных преимуществ. Для принятия решения по инвестированию в стратегии развития применяется математическая модель линейного программирования. Рассмотрены задачи оценки эффективности развития в направлении расширения количества потребителей услуг. Сформирована сетевая модель в виде причинно-следственной диаграммы для исследования взаимовлияния факторов объема продаж. Рассмотрено экономическое проявление синергетического эффекта компаний при реализации стратегии слияния. Для исследования интенсивностей потоков данных в объединенной сети используется модель потоков данных многоуровневой структуры. Выводы: В результате возрастающих объемов и неоднородности трафика инфокоммуникационных сетей операторами связи применяют стратегии слияния для объединения ресурсов управления сетью. При этом возникает синергетический эффект факторов, влияющих на объемы услуг. Исследование изменений трафика и эффективности структуры объединенной сети проводится на основе трехуровневой иерархической модели. Направлением дальнейших исследований является моделирование нагрузки сети с различными характеристиками технической структуры для оценки эффективности стратегии реинжиниринга.

Ключевые слова: операторы связи; сети передачи данных; стратегии развития; влияние факторов; интенсивность трафика. 